\title{
Donald W. Treadgold: 1922-1994
}

Professor Donald Warren Treadgold died unexpectedly from acute leukemia on 13 December, 1994. He was born 72 years ago in Silverton, Oregon. He earned his B.A. degree in 1943 at the University of Oregon. His studies were interrupted by military service between 1943 and 1946 in Europe where he rose to rank of captain in the military intelligence. In 1947 he earned his Master's degree at Harvard and his Doctor of Philosophy three years later at Oxford. In 1949 he joined the University of Washington from which he retired at the end of June 1993.

To most colleagues Professor Treadgold is best known as a superb scholar. His first book, Lenin and His Rivals (Praeger) was published in 1955 (reprinted by Greenwood, 1976). Two years later Princeton University Press brought out The Great Siberian Migration (also reprinted by Greenwood, 1976). His widely known and used Twentieth Century Russia was first published in 1959 by Rand-McNally. The eighth, totally reworked and rewritten edition of this work was published posthumously by Westview Press. Next came the two-volume The West in Russia and China (Cambridge University Press, 1973-reprinted in 1985 by Westview) in preparation for which Professor Treadgold learned Chinese. I recall walking into his office while he worked on his Chinese. He called me over and showed me some, to me meaningless, signs and said, "It took me hours to figure out that these stand for Aristotle." He certainly did not use easy or standard texts to learn a language!

His publications continued with A History of Christianity (Nordland, 1979) the revision of which was left unfinished by its author's untimely death. Freedom: A History (New York University, 1990) was the last volume Professor Treadgold wrote, but certainly not his last publication. He constantly worked on revisions of older works, on his literally hundreds of articles, lectures and book reviews and on editing The Devel. opment of the USSR (1964) and Soviet and Chinese Communism (1967) both by the University of Washington Press. He co-edited (with Larry Lerner) Gorbachev and the Soviet Future (Westview, 1988) and with me seven of the planned ten volumes of A History of East-Central Europe. His last editorial enterprise, Render unto Caesar: Religion and World Politics (co-edited with Sabrina Ramet) will be published in 1995 by the American University Press.

Besides writing his own volumes and editing several others, Professor Treadgold found time to write chapters, introductions and essays for several other volumes. I am certain that I did not discover all when I counted 27 of these.

Donald Treadgold, the editor, is well known to all readers of the Slavic Review. The first issue of the AAASS's journal published under this title (October 1961) was the third issue which listed him as the Managing Editor. Numbers 1 and 2 of Volume $\mathrm{xx}$ still appeared as The American Slavic and East European Review and included a new feature, the Discussion Section. It is generally recognized that under his management, 1961-1964, Slavic Review became a first-rate scholarly journal. Nothing proves this better than the fact that when the publication ran into some difficulties again, it was Professor Treadgold who was asked to resume the job of Managing Editor for a second time, 1968-1975, although he had to add this burden to the already time-consuming position of Chairman of the History Department. This was typical of Donald Treadgold who never refused to step in when help was needed by an organization or a friend.

His editorial success was the result of another Treadgold characteristic, thoroughness. Because he did me the honor and asked me repeatedly to work with him on the Slavic Review, I was able to observe him at work. I think he is the only editor I ever knew who would not approve anything for publication until he checked out every footnote to make certain that they were absolutely correct! That this took much time, did not matter to him; he had to do what he considered to be the proper and required job.

Slavic Review 54, no. 2 (Summer 1995) 
To do things properly and correctly was part of Donald Treadgold's characteristics and values. Added to this was a certain noblesse oblige which made him accept as signments from the Department of History and what was known under various names during his years of service and is today the Jackson School of the University of Wash. ington as well as the American Historical Association, AAASS, and numerous other national and international scholarly organizations all of whom he served in numerous capacities with distinction. The list is too long to include the numerous services to all of these. I will mention only a few: Chairman of the History Department for ten years, Acting Chairman of what is now the Jackson School on more than one occasion; President of AAASS (1977); Program Committee Chairman for the III World Congress of International Committee on Soviet and East European Studies; Chairman of the Academic Advisory Committee of the Kennan Institute; Chairman of the Joint Committee on Slavic Studies of ACLS and many others.

That the abilities of a scholar of Professor Treadgold's stature were recognized is no surprise. Once again, I will limit myself to listing only some of the major awards and honors he received during his distinguished career. These include a Rhodes Scholarship; a Ford Foundation Fellowship; a Rockefeller Foundation Grant; a Guggenheim Fellowship; the E. Harrison Harbison Award for Distinguished Teaching; the Phi Beta Kappa Scholar nomination; the AAASS Award for Distinguished Service and another for Distringurśned Contríbutions to Slavíc Studies; the University of Washington Annual Faculty Lectureship; Scholar in Residence, Villa Serbelloni in Bellagio and finally an election as a Fellow of the American Academy of Arts and Sciences.

The above mentioned Harbison Award indicates that Professor Treadgold was an exceptional teacher of both graduates and undergraduates while upholding the highest academic standards and values. His interest in his students went way beyond the classroom. Every day when the university was in session, he appeared at 9:30 in the cafeteria of the Student Union where any student could join him and discuss academic, national, world and private problems with him. The number of foreign students who found out what Thanksgiving is by joining the Treadgolds is large. His students became attached to him for life. At every AAASS meeting members of The Gang, as these exstudents call themselves, had a reunion dinner with their master and friend. Not only the students of the University of Washington profited from Professor Treadgold's ability to share his knowledge. He gave lectures at some fifty other institutions and served as visiting professor/scholar at the National University at Taipei, the University of Hawaii, the Academy of Sciences in Moscow and Toyo Bunko in Tokyo.

Students were not the only ones who profited from Professor Treadgold's interest in their wellbeing and from his friendship. So did numerous colleagues, including myself. As I wrote elsewhere: "Don was a man who fostered not only his own but many other careers with his encouragement and suggestions. He had his own vision of things, but he was able and willing to listen to those of others..." He not only listened but helped when he could. In a letter which I received from a respected colleague after Professor Treadgold's death I read: “. . when I wrote something for publication I usually had Don in mind as my main reader. I wanted what I wrote to be something that he would approve..." The number of colleagues who thought this way and were helped by both criticism and approval they received from Donald Treadgold is numerous indeed.

We lost a great scholar and teacher, but those of us-and this includes a great number of friends all over the world-lost an exemplary human being. I already wrote about his helpfulness, his belief that things must always be done as well as one's ability permits, but if I have to list his main characteristics, I must begin with loyalty. This belonged, first, foremost and always to his family for whom he always had time even in the midst of the most hectic circumstances. His love for them was boundless and unconditional. He was more proud of them than of anything else in life. Next came his friends. Even if they disappointed him on occasion, they remained his friends and their weaknesses were overlooked.

Next to loyalty, I would list self-discipline as the next prominent feature we learned to observe and respect. All of us make plans, give ourselves deadlines, map out our 
next steps, but only seldom do things and events turn out as we planned. Donald Treadgold was the exception. His plans and time tables worked because he had himself fully in control. Most of us with teaching experience know that it takes time to get "out of the class room" mentally and begin working on an article or book. Professor Treadgold could switch from one activity to another at will when his time schedule demanded it. This included not only work. I always marveled when we shared a room at a meeting or convention when my roommate declared, "Time to sleep"; turned around and was asleep. I also admired his ability to say "I am wrong" in the few instances when this was required. Honesty, another of his character traits, demanded this from him. His ability to absorb and retain information was incredible. He read everything, knew what he read and where he read a given bit of information.

Donald Treadgold loved travel, good food, fine wines. He loved classical music, especially opera, and relaxed in the swimming pool and on the handball court. This much everybody knew who had more than a passing acquaintance with him. What most people did not realize was that he had a magnificent sense of humor and ap. preciated a good joke, even a practical one at his expense. This is something those of us who had lunch with him regularly will miss together with everything else which he represented. Their feeling of loss is shared by the many colleagues and friends, in and out of academia, all over the world who profited from Professor Treadgold's help and advice, enjoyed his company and loved him. I am certain that Professor Treadgold had his weaknesses and faults like all human beings, but well and closely as I knew him, I cannot think of anything that would have bothered me in his case.

Peter F. Sugar

Professor Emeritus

University of Washington 